\title{
Universiteit
}

Leiden

The Netherlands

\section{Subcellular localization of the nodD gene product in Rhizobium leguminosarum}

Schlaman, W.R.M.; Spaink, H.P.; Okker, R.J.; Lugtenberg, E.J.J.

\section{Citation}

Schlaman, W. R. M., Spaink, H. P., Okker, R. J., \& Lugtenberg, E. J. J. (1989). Subcellular localization of the nodD gene product in Rhizobium leguminosarum. Journal Of Bacteriology, 171(9), 4686-4693. doi:10.1128/jb.171.9.4686-4693.1989

Version: $\quad$ Not Applicable (or Unknown)

License: $\quad$ Leiden University Non-exclusive license

Downloaded from: https://hdl.handle.net/1887/46860

Note: To cite this publication please use the final published version (if applicable). 


\title{
Subcellular Localization of the nodD Gene Product in Rhizobium leguminosarum
}

\author{
HELMI R. M. SCHLAMAN, * HERMAN P. SPAINK, ROBERT J. H. OKKER, \\ AND BEN J. J. LUGTENBERG \\ Department of Plant Molecular Biology, Leiden University, Nonnensteeg 3, \\ 2311 VJ Leiden, The Netherlands
}

Received 9 February 1989/Accepted 1 June 1989

\begin{abstract}
In Rhizobium strains the transcription of symbiosis plasmid-localized nod genes, except nodD, is induced by plant flavonoids and requires the nodD gene product. In order to localize NodD protein in $R$. leguminosarum, a NodD protein-specific antiserum was raised against a lac $Z^{\prime}$-' nodD gene fusion product. Using these antibodies, we determined that the NodD protein is located exclusively in the cytoplasmic membrane of wild-type $R$. leguminosarum biovar viciae cells. This localization is independent of the presence of inducers. In a Rhizobium strain that overproduced the NodD protein, the protein was present both in the cytoplasmic membrane and the cytosol, indicating an influence of the protein abundance on its ultimate subcellular localization. It was estimated that 20 to 80 molecules of NodD protein were present per wild-type Rhizobium cell. A model which combines the localization and the DNA-binding properties of the NodD protein as well as the observed association of flavonoids with the cytoplasmic membrane is discussed.
\end{abstract}

Soil bacteria of the genus Rhizobium are able to establish a symbiosis with leguminous plants by forming root nodules in which, after differentiation of the bacteria to bacteroids, atmospheric nitrogen is fixed. Differentiation of Rhizobium species and biovars is based on their ability to successfully nodulate a particular group of host plants. It has been known for some years that certain bacterial genes which are located on a large Sym (symbiosis) plasmid are involved in important stages of nodule formation. Some of these nod genes are functionally interchangeable between different Rhizobium species, and they have therefore been designated as common nod genes, while other genes determine the host specificity of nodulation ( $h s n$ genes). The transcription of these Sym plasmid-localized nod genes, except $\operatorname{nod} D$, is induced by plant flavonoids and requires the presence of the NodD protein. The nodD gene, one copy of which is present in Rhizobium leguminosarum biovar viciae and $R$. leguminosarum biovar trifolii and three copies of which are found in Rhizobium meliloti, is transcribed constitutively (5).

Although the nodD gene has been designated a common nod gene, it has recently been established that the response of the nodD gene product toward various inducers depends upon its bacterial origin (38). The importance of each of the different nodD genes present in $R$. melilot $i$ is reflected by the fact that nodulation of different host plants is impaired by mutations in different nodD genes $(10,14,15)$. Therefore, a direct interaction between the NodD protein and inducing flavonoids is likely. Studies with homologous recombinants of the nodD genes of $R$. meliloti and $R$. leguminosarum biovar trifolii (37) support this hypothesis, since several of these nodD hybrid genes show novel types of responses toward flavonoids compared with the responses of the parental nodD genes.

Conserved DNA sequences, so-called nod boxes (29), have been identified upstream of the inducible nod genes. These may play a role in transcription activation, as it has been shown by using deletion mutants in this region that the

* Corresponding author. promoter overlaps the nod box (35). Transcriptional start sites of $\operatorname{nod} A, \operatorname{nod} F$, and $\operatorname{nod} H$ are only 24 to 28 base pairs (bp) downstream of the consensus nod box sequence $(9,36)$. Studies with DNA fragments containing nod box sequences and either cell extracts of NodD protein-overproducing strains or partially purified NodD protein have shown that NodD protein binds to nod boxes $(8,13)$. This binding is specific for DNA containing nod box sequences and is independent of the presence of an inducer. Another property of NodD protein is autoregulation, which has been found in $R$. leguminosarum biovar viciae and $R$. leguminosarum biovar trifolii but not, or to a lesser extent, in $R$. meliloti $(24$, 28,37 ). This property is probably caused by binding of the NodD protein to DNA as well.

The nucleotide sequences of the nodD genes of $R$. leguminosarum biovar viciae, $R$. leguminosarum biovar trifolii, $R$. meliloti, Rhizobium japonicum, and Bradyrhizobium species are highly conserved $(1,6,32-34)$ and share homology with several DNA-binding transcriptional activator proteins which constitute the LysR family (12). Homology of the NodD protein with the transcriptional activator AraC protein of Escherichia coli has been proposed as well (34), and there exists a great resemblance of the NodD protein with the recently published sequence of the NahR protein, a regulator of the genes involved in naphthalene degradation in Pseudomonas putida $(31,44)$.

The binding of the NodD protein to nod boxes and its homology with other transcriptional activator proteins suggest a cytoplasmic localization. We investigated the localization of the NodD protein and found that it is localized exclusively in the cytoplasmic membrane of wild-type $R$. leguminosarum biovar viciae cells. This localization is even more interesting since other recent work from our laboratory (27) shows that naringenin, a NodD protein activator, has a very high affinity for the cytoplasmic membrane. In view of these data, we present a model for the interaction of NodD protein, inducing compounds, and regulated nod gene promoters. 
TABLE 1. Plasmids used in this study ${ }^{a}$

\begin{tabular}{|c|c|c|}
\hline Plasmid & Relevant characteristics & Reference \\
\hline pMP97 & $\begin{array}{l}\text { IncColE1 carrying } K p n \mathrm{I}, C l a \mathrm{I} \text { fragment of pRL1JI, which contains the entire } \\
n o d D, 5 \text { parts of } n o d A \text { and } n o d F, \text { and intergenic regions }\end{array}$ & This study \\
\hline pMP98 & IncP carrying pr. nodD-nod $D^{\prime}$, which was used as a negative control of pMP238 & This study \\
\hline pMP154 & IncQ carrying pr. nodA-lac $Z$ & 35 \\
\hline pMP235 & IncP carrying a deletion in $n o d A-n o d D$ intergenic region & This study \\
\hline pMP237 & IncColE1, IncP carrying pr. lac-nodD; pr. nodA and pr. nodD were both deleted & This study \\
\hline pMP238 & IncP carrying pr. nodA-nodD & This study \\
\hline pMP280 & IncP carrying pr. nodD-nodD & 38 \\
\hline pMP300 & IncP carrying a deletion in nodA-nodD intergenic region; pr. nodA present & 35 \\
\hline pMP2001 & IncColE1 carrying pr. lac-lacZ'-nodD & This study \\
\hline pMP2002 & $\begin{array}{l}\text { Like pMP2001, but the lac } Z \text { sequences were reversed; used as a negative control } \\
\text { of pMP2001 }\end{array}$ & This study \\
\hline pMP2003 & Like pMP237, but pr. lac was reversed; used as a negative control of pMP237 & This study \\
\hline
\end{tabular}

"All nod sequences were from pRL1JI. Abbreviation: pr., Promoter.

\section{MATERIALS AND METHODS}

Bacterial strains and plasmids. E. coli JM101 [supE thi $\Delta$ (lac-proAB) $\left(\mathrm{F}^{\prime}\right.$ traD36 proAB lac $\left.\left.I^{\mathrm{q}} \mathrm{Z} \Delta \mathrm{M} 15\right)\right](43)$ was used for propagation of plasmids and for production of the lac $Z^{\prime}$ 'nodD gene fusion product. $R$. leguminosarum biovar viciae wild-type strain 248 (16) and its Sym plasmid pRL1JI-cured derivative RBL1387 (26) were used for protein localization studies. Strain RBL1387 was used as a host for recombinant plasmids. Nodulation assays were performed on Vicia sativa var. nigra with $R$. leguminosarum RBL5560 (wild-type nod genes) and RBL5561 (nodD::Tn5) (45), with the latter one carrying a recombinant plasmid containing pRL1JI nodD. All plasmids used in this study are listed in Table 1.

DNA manipulation and bacterial crosses. Restriction endonucleases, T4 DNA ligase, nuclease $B a l$ 31, DNA primer, and unlabeled nucleotides were purchased from Boehringer $\mathrm{GmbH}$ (Mannheim, Federal Republic of Germany). Freezedried large fragment (Klenow) of DNA polymerase I was obtained from Bethesda Research Laboratories (Gaithersburg, Md.), and $\left[\alpha^{-35}\right.$ S $]$ dATP was purchased from Amersham International plc (Amersham, United Kingdom). Nucleotide sequencing was performed as described previously (30). All DNA manipulations were performed essentially as described by Maniatis et al. (19). Transfer of IncP plasmids from $E$. coli JM101 to $R$. leguminosarum RBL1387 was performed by using a triparental mating as described previously (4). Strains carrying plasmids were selected on solid medium supplemented with $100 \mu \mathrm{g}$ of ampicillin $\mathrm{ml}^{-1}$ or 20 and $2 \mu \mathrm{g}$ of tetracycline $\mathrm{ml}^{-1}$ for $E$. coli and $R$. leguminosarum, respectively. Rifampin $\left(20 \mu \mathrm{g} \cdot \mathrm{ml}^{-1}\right)$ was used for selection against $E$. coli in bacterial crosses.

Construction of lacZ' -' nodD gene fusion. Plasmid pMP97, which was derived from pIC20H (21), contained a 2.4kilobase KpnI-ClaI fragment of pRL1JI coding for the entire nodD gene and the 5 '-terminal parts of $\operatorname{nod} A$ and $\operatorname{nod} F$. The 5 'terminal 192 bp of $l a c Z$ were cloned as a Sau3A fragment of pIC20H in BamHI-digested pMP97, resulting in pMP2001. This vector contained the lac $Z^{\prime}-{ }^{\prime}$ nodD translational gene fusion downstream of the lac promoter (Fig. 1A). Plasmid pMP2002, which was constructed in the same way, contained an inverted lac Z Sau3A fragment.

Construction of NodD protein-(over)producing plasmids. A 114-bp $B c / I-B g l$ II fragment containing the nod $A$ promoter and part of the nodD promoter of pRL1JI was treated with $B a l 31$ starting from the $B c / I$ site (35). After ligation with a $K p n I$ linker at the $3^{\prime}$ end and nucleotide sequencing, the IncP plasmid pMP235, which contained a 36-bp fragment with 18 $\mathrm{bp}$ in front of the nodD-coding region, was isolated. The $B g l$ II fragment of pMP97, which contained nodD sequences, was cloned into $B g$ lII-digested pMP235, resulting in pMP236. For overproduction of NodD protein in E. coli, pMP237 was constructed by cloning KpnI-linearized pMP236 downstream of the lac promoter in pIC20H. Plasmid pMP2003, which was used as a negative control for pMP237, contained the lac promoter in the opposite direction (Fig. 1A). For overproduction of NodD protein in $R$. leguminosarum, a PstI-KpnI fragment of pMP300 (35) containing the nodA promoter with only 33 adjacent nucleotides $3^{\prime}$ of the nod box consensus sequence was inserted upstream of the nodD gene and its preceding $18 \mathrm{bp}$ in pMP236, resulting in pMP238 (Fig. 1A). Plasmid pMP98, which was used as a negative control, and plasmid pMP280 (38) are both broad-host-range IncP plasmids containing the $\mathrm{pRL} 1 \mathrm{JI}$ nodD promoter. In addition, pMP98 contained nodD sequences upstream of the Bam HI site and pMP280 contained the complete nodD gene.

Production of antibodies against NodD protein. E. coli JM101(pMP2001) was grown for $16 \mathrm{~h}$ in LC medium (19) supplemented with ampicillin and $20 \mu \mathrm{g}$ of isopropyl- $\beta$ D-thiogalactopyranoside (IPTG) $\mathrm{ml}^{-1}$. Bacteria were lysed after twofold dilution in sample buffer by boiling them for 10 min. Total cell proteins were separated on sodium dodecyl sulfate (SDS)-11\% polyacrylamide gels (18). Gels were stained for $30 \mathrm{~min}$ in $0.2 \%$ (wt/vol) Coomassie brilliant blue in $10 \%$ acetic acid-50\% methanol, and after the gels were destained in the same solvent for $30 \mathrm{~min}$, the protein band of 31 kilodaltons $(\mathrm{kDa})$ (Fig. $2 \mathrm{~A}$, lane 4 , indicated by a solid arrow) was isolated by electroelution by the method of Hager and Burgess (11). An amount of $100 \mu \mathrm{g}$ of this material, which was suspended in Freund complete adjuvant (1:1), was injected subcutaneously into a New Zealand White rabbit, and a booster injection without adjuvant was given after 1 month. Antiserum was collected 10 days after the booster injection.

Cell fractionation. Wild-type $R$. leguminosarum or strains carrying a recombinant plasmid were grown for $16 \mathrm{~h}$ in 400 $\mathrm{ml}$ of TYB medium, consisting of TY medium (2) to which $20 \%(\mathrm{vol} / \mathrm{vol})$ of $\mathrm{B}^{-}$medium (40) was added, in the presence or absence of $1.0 \mu \mathrm{M}$ naringenin. After harvesting, the cell pellet was suspended in $10 \mathrm{ml}$ of ice-cold $50 \mathrm{mM}$ Tris hydrochloride ( $\mathrm{pH} \mathrm{8.5)-20 \%} \mathrm{(wt/vol)} \mathrm{sucrose-0.2} \mathrm{mM} \mathrm{dithio-}$ threitol supplemented with $200 \mu \mathrm{g}$ of each of DNaseI and RNase A (Sigma Chemical Co., St. Louis, Mo.) $\mathrm{ml}^{-1}$. The following protease inhibitors, all of which were purchased 
from Sigma, were added to the suspended cells unless indicated otherwise: phenylmethylsulfonyl fluoride (200 $\mu \mathrm{M})$, soybean trypsin inhibitor $\left(50 \mu \mathrm{g} \cdot \mathrm{ml}^{-1}\right)$, and leupeptin $(20 \mu \mathrm{M})$. The bacteria were broken by three passages through a French pressure cell at $15,500 \mathrm{lb} / \mathrm{in}^{2}$, and cell fractions were isolated as described previously (3). Lysozyme and $\mathrm{KCl}$ were added to the cell lysate to final concentrations of $200 \mu \mathrm{g} \cdot \mathrm{ml}^{-1}$ and $0.2 \mathrm{M}$, respectively, and after incubation on ice for $40 \mathrm{~min}$, membranes were collected by centrifugation for $2 \mathrm{~h}$ at $120,000 \times g$ at $4^{\circ} \mathrm{C}$. The membrane fraction was suspended in 600 to $800 \mu \mathrm{l}$ of $15 \%(\mathrm{wt} / \mathrm{wt})$ sucrose-5 mM EDTA ( $\mathrm{pH} 7.5)-0.2 \mathrm{mM}$ dithiothreitol; and the inner and outer membranes of $500 \mu$ l of total membranes were separated in a discontinuous sucrose gradient consisting of $1.5 \mathrm{ml}$ of $60 \%, 4.0 \mathrm{ml}$ of $40 \%, 4.5 \mathrm{ml}$ of $25 \%$, and 0.5 $\mathrm{ml}$ of $15 \%$ (wt/wt) sucrose in $5 \mathrm{mM}$ EDTA (pH 7.5)-0.2 mM dithiothreitol. Fractions of $0.5 \mathrm{ml}$ were collected from the top of the gradient, and their protein contents were determined by measuring the $A_{280}$. The purity of the membrane fractions was established by measuring NADH oxidase activity (25), a cytoplasmic membrane marker, and by protein pattern analysis in SDS-polyacrylamide gels. These procedures can be used to prove the purity of membrane fractions (3). To concentrate membrane material, sucrose gradient fractions containing either cytoplasmic or outer membranes were pooled and centrifuged for $2 \mathrm{~h}$ at $120,000 \times$ $g$ at $4^{\circ} \mathrm{C}$. The pellets were suspended in $100 \mu \mathrm{l}$ of $15 \%$ (wt/vol) sucrose-5 mM EDTA ( $\mathrm{pH} 7.5)-0.2 \mathrm{mM}$ dithiothreitol.

Periplasmic and cytoplasmic fractions were isolated as described previously (3).

The proteins that were present in the culture supernatant and in the soluble fraction of broken cells were precipitated by the addition of trichloroacetic acid to a final concentration of $5 \%(\mathrm{wt} / \mathrm{vol})$ and incubation at $0^{\circ} \mathrm{C}$ for $60 \mathrm{~min}$. Precipitates were collected by centrifugation for $10 \mathrm{~min}$ at $3,000 \times g$ at $4^{\circ} \mathrm{C}$ and solubilized in 4 and $1.2 \mathrm{ml}$ of $10.0 \mathrm{mM}$ Tris hydrochloride $(\mathrm{pH} 7.5)-0.2 \mathrm{mM}$ dithiothreitol, respectively. All samples were stored frozen at $-20^{\circ} \mathrm{C}$ until use.

Protein analysis and immunoblotting. Proteins of whole cells or cell fractions were separated on SDS-11\% polyacrylamide gels (18) and either stained with fast green (18) or transferred to nitrocellulose (39). The nitrocellulose was blocked with blocking buffer $(1 \%$ [wt/vol] bovine serum albumin in $10 \mathrm{mM}$ sodium phosphate [pH 7.0]-0.9\% [wt/vol] sodium chloride) for $1 \mathrm{~h}$ at room temperature. Subsequently, the nitrocellulose sheets were incubated for $2 \mathrm{~h}$ with antiserum against the NodD protein or $E$. coli $\beta$-galactosidase (a kind gift from J. van Duyn, Department of Biochemistry, Leiden University, Leiden, The Netherlands) diluted 2,000and 100-fold, respectively, in blocking buffer. After washing for $1 \mathrm{~h}$ with Tween-buffer $(0.1 \%$ Tween 20 in $10 \mathrm{mM}$ sodium phosphate [pH 7.0]-0.9\% [wt/vol] sodium chloride), the blots were incubated for $1 \mathrm{~h}$ with 2,000-fold-diluted alkaline phosphatase-conjugated goat anti-rabbit immunoglobulins (Sigma) in blocking buffer. After subsequent washing for $1 \mathrm{~h}$ in Tween-buffer, the reaction was visualized by using naphthol AS-MX phosphate and fast red TR salt (both from Sigma) as substrates (41).

Calculation of the number of molecules of NodD protein. The protein p31 (Fig. 2A, lane 4, indicated by a solid arrow) was isolated as described above. To remove the Coomassie brilliant blue stain from the protein, lyophilized powder was solubilized in $100 \mu \mathrm{l}$ of water and $900 \mu \mathrm{l}$ of cold acetone (P. A.; Merck AG, Darmstadt, Federal Republic of Germany) was added. After incubation for $30 \mathrm{~min}$ at $4^{\circ} \mathrm{C}$, the sample was centrifuged for $15 \mathrm{~min}$ at $10,000 \times g$ at $4^{\circ} \mathrm{C}$. The pellet was suspended in $100 \mu \mathrm{l}$ of water, and the acetone precipitation was repeated twice. The resulting white protein pellet was lyophilized and solubilized in water, and its protein content was determined by the method described by Markwell et al. (20) by using bovine serum albumin as a standard. Various known amounts of p31 were electrophoresed on SDS-polyacrylamide gels, and immunological detection was performed as described above. The same gels were also loaded with various dilutions of total membranes of $R$. leguminosarum biovar viciae wild-type strain 248 . The amount of cells, from which this membrane material was derived, was estimated by counting the number of viable cells of the original culture. The number of NodD protein molecules present per wild-type Rhizobium cell was estimated by assuming an equal immunoreactivity of both antigens, p31 and the NodD protein.

\section{RESULTS}

Expression of nodD gene in $E$. coli and production of antibodies against NodD protein. In order to isolate NodD protein for the production of antiserum, pMP237 was constructed (Fig. 1). This plasmid contained the entire nodD gene of pRL1JI under control of the inducible lac promoter. $E$. coli JM101(pMP237) produced detectable amounts of a 34-kDa protein in the presence, but not in the absence, of IPTG (Fig. 2A, lanes 7 and 8, respectively). This apparent molecular mass is in very good agreement with the predicted size of the NodD protein (34.5 $\mathrm{kDa}$ [34]). The $34-\mathrm{kDa}$ protein was not detected in $E$. coli JM101 carrying the control plasmid pMP2003 (Fig. 2A, lanes 5 and 6). The amount of nodD gene product produced by $E$. coli JM101(pMP237) was rather low, presumably because of weak translation initiation. In an attempt to enhance the expression level, we constructed pMP2001 (Fig. 1), which contained a lac $Z^{\prime}$ 'nodD chimeric gene downstream of the lac promoter. Only upon induction of $E$. coli JM101(pMP2001) with IPTG were six dominant protein bands detected in profiles of whole-cell proteins (Fig. 2A; compare lanes 3 and 4). The apparent molecular size of the slowest-moving protein, which was part of a doublet, corresponded with the predicted size of the fusion protein $(33 \mathrm{kDa})$ and showed the strongest immunoreaction with antibodies against $\beta$-galactosidase (data not shown). The control strain $E$. coli JM101(pMP2002) did not produce any of these six proteins (Fig. 2A, lanes 1 and 2).

The protein with an apparent molecular mass of $31 \mathrm{kDa}$ (designated p31 and indicated by a solid arrow in Fig. 2A) was subsequently used to raise antibodies because it could be excised from the gel with minimal contamination of the other visible proteins.

The smaller proteins produced by E. coli JM101(pMP2001) upon induction were probably degradation products of the entire LacZ' -'NodD fusion protein that arose from specific cleavage by host proteases in vivo, since (i) all these proteins showed an immunoreaction with antibodies against p31 (Fig. $2 B$, lane 4) and (ii) they did not disappear when bacteria were lysed in the presence of protease inhibitors (data not shown).

Overproduction of NodD protein in $R$. leguminosarum. Initially, we were not able to detect NodD protein in total cell proteins of wild-type $R$. legumonisarum biovar viciae 248 using the antiserum raised against $\mathrm{p} 31$. Therefore, NodD protein-overproducing Rhizobium strains were constructed. When the copy number of nodD was increased approximately fivefold by introduction of the IncP plasmid pMP280 in $R$. leguminosarum RBL1387, NodD protein still could not 


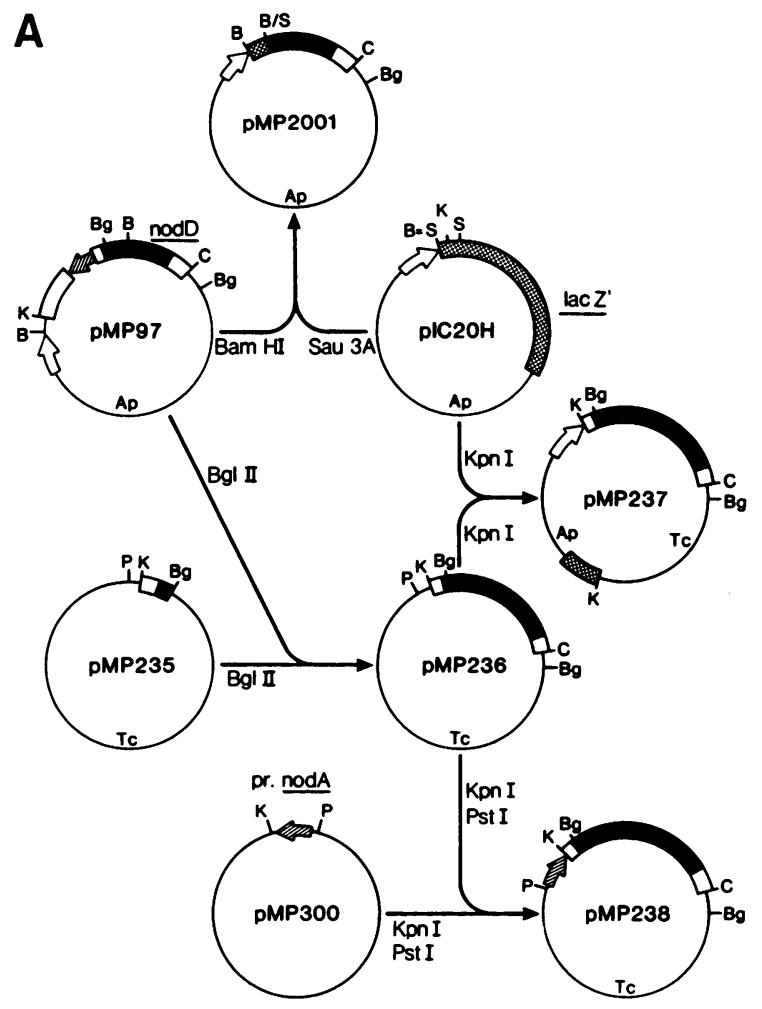

B

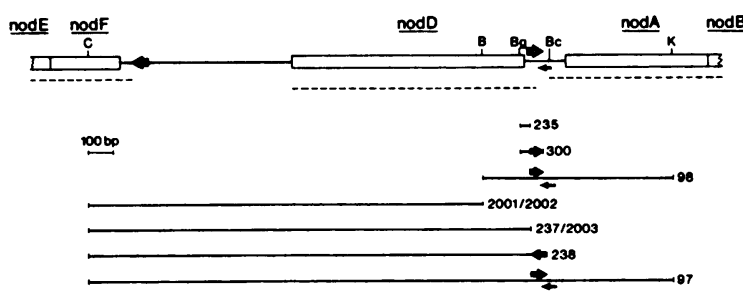

FIG. 1. (A) Construction of plasmids used in this study. pMP2001 contained the lacZ'-'nodD chimeric gene downstream of the lac promoter. pMP237 and pMP238 were both expression plasmids for the NodD protein; they both contained the entire nodD gene of pRL1JI downstream of the lac and nodA promoters, respectively. The construction of negative control plasmids was performed in an analogous way (data not shown). In pIC20H, only Sau3A sites of interest are indicated. Black boxes indicate nodD sequences; dotted boxes indicate lac $Z$ sequences. Adjacent nod DNA is represented by open boxes. Shaded and open large arrows represent nodA and lac promoters, respectively. (B) nod sequences present in different plasmids. Part of the nod region present in pRL1JI is given, with open reading frames indicated by boxes. Dotted lines and shaded and black arrows represent transcripts and inducible and constitutive promoters, respectively. pMP235 and pMP300 both contained deletions of the nodD-nodA intergenic region. pMP235 contained the first $37 \mathrm{bp}$ of nodD (until the Bg/II site) and $18 \mathrm{bp}$ upstream of the nodD open reading frame. pMP300 has been described previously (35). Plasmids given in panel A are not drawn to scale. Abbreviations: $A p$ and $T c$, ampicillin and tetracycline resistance regions, respectively. Restriction sites: $B$, BamHI; B/S, BamHI-Sau3A junction; Bc, BclI; Bg, BglII; C, ClaI; K, KpnI; P, PstI; S, Sau3A.

be detected in the protein profiles of total cells. Because inducible nod promoters showed a high level of expression upon induction, we cloned the nodD gene of pRL1JI downstream of the nodA promoter (pMP238 in Fig. 1). R. legu-

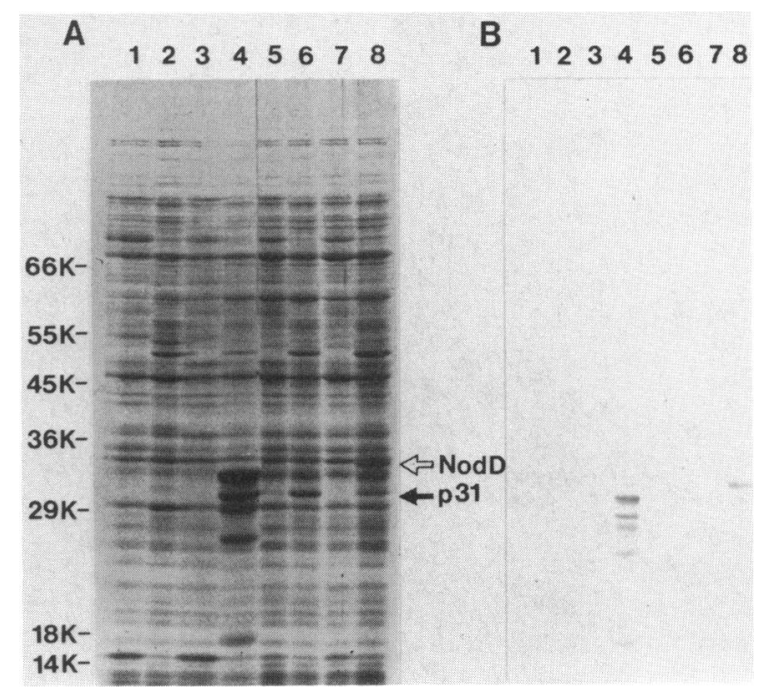

FIG. 2. Western blot (immunoblot) analysis of proteins expressed in $E$. coli by using antibodies raised against p31. (A) Profiles of total cell proteins obtained on a SDS-polyacrylamide gel after fast green staining. The positions of $\mathrm{p} 31$ and NodD are indicated by solid and open arrows, respectively. (B) Immunological identification of fusion protein bands and the NodD protein directed by pMP2001 and pMP237, respectively, in whole-cell proteins of $E$. coli JM101. The samples represent $E$. coli JM101 containing pMP2002 (lanes 1 and 2), pMP2001 (lanes 3 and 4), pMP2003 (lanes 5 and 6), or pMP237 (lanes 7 and 8) grown in the absence (odd lanes) or presence (even lanes) of IPTG. The positions of molecular weight markers ( $K$ indicates $10^{3}$ ) are given in the left margin.

minosarum RBL1387(pMP238) produced a 34-kDa protein in visible amounts on stained gels, provided that the cells were grown in the presence of one of the inducers naringenin or luteolin (data not shown). This result, in combination with the predicted molecular mass, strongly suggests that the 34-kDa protein is identical to the NodD protein. This notion was further supported by the following experiments, which showed that upon induction a strain carrying pMP238 produces a functional NodD protein with respect to nod gene activation and nodulation. (i) $R$. leguminosarum RBL5561, harboring both pMP238 and the nodA promoter-lac $Z$ transcriptional fusion pMP154, produced $250 \mathrm{U}$ of $\beta$-galactosidase (22) in the absence of inducer and $18,000 \mathrm{U}$ of $\beta$ galactosidase upon induction with naringenin. (ii) $R$. leguminosarum RBL5561, with a Tn5 insertion in nodD, was not able to nodulate $V$. sativa. However, strain RBL5561(pMP238) showed the same nodulation phenotype on $V$. sativa plants as that of wild-type strain RBL5560.

Specificity of antibodies against p31. To test the specificity of the antiserum against p31 in R. leguminosarum, total cell proteins of RBL1387(pMP238) were analyzed by using Western blots (immunoblots). Only the putative NodD protein band reacted with the antiserum (Fig. 3, lane 2). No reaction was observed with material derived from $R$. leguminosarum RBL1387(pMP98) (Fig. 3, lane 1) or with total cell proteins of $R$. leguminosarum biovar viciae wild-type strain 248 (data not shown). As a control, total cell proteins of $E$. coli JM101(pMP237) were analyzed as well. Several faint bands and one very pronounced band were observed (Fig. 3, lane $4)$, the last of which corresponded with a protein of $34 \mathrm{kDa}$, which was absent in crude lysates of $E$. coli JM101(pMP2003) (Fig. 3, lane 3). Thus, the antiserum was specific toward the NodD protein in both $R$. leguminosarum and $E$. coli. 


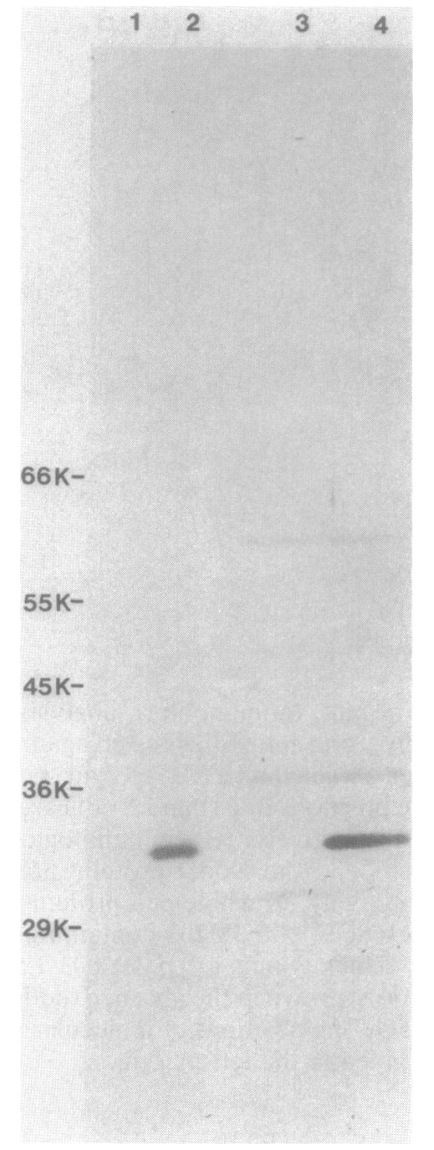

FIG. 3. Specificity of antibodies raised against $\mathrm{p} 31$. Proteins of whole cells of $R$. leguminosarum RBL1387(pMP98) (lane 1) and RBL1387(pMP238) (lane 2) and E. coli JM101(pMP2003) (lane 3) and JM101(pMP237) (lane 4) were separated on SDS-polyacrylamide gels. Western blots were incubated with antiserum against p31. Rhizobium and $E$. coli cells were induced with naringenin and IPTG, respectively. The positions of molecular weight markers ( $\mathrm{K}$ indicates $10^{3}$ ) are given in the left margin.

Subcellular localization of NodD protein in an overproducing Rhizobium strain. To investigate the localization of the NodD protein in NodD protein-overproducing strains, cultures of RBL1387(pMP238) were initially fractionated into medium components, soluble cell proteins, and total membranes. By using electrophoresis and fast green staining, the NodD protein could only be detected in the total membrane fraction of induced cells (data not shown). Using Western blotting, however, we detected NodD protein both in the membrane fraction and, although to a slightly lesser extent, in the soluble cell-protein fraction as well (Fig. 4, lanes 5 and 6). After separation of the two membranes, the NodD protein was found in the cytoplasmic membrane fraction but not in the outer membrane fraction (Fig. 4, lanes 7 and 8). Subsequent isolation of periplasm and cytoplasm indicated that the NodD protein was present in the cytoplasm but not in the periplasm (data not shown). A positive reaction was not detected on Western blots of cell fractions of noninduced $R$. leguminosarum RBL1387(pMP238) (Fig. 4, lanes 1 to 4), unless the lanes were at least eightfold overloaded, or with the control strain $R$. leguminosarum RBL1387(pMP98) grown either in the presence or in the absence of flavonoid inducers (data not shown). In conclusion, the nodD gene product is localized in the cytoplasmic membrane as well as

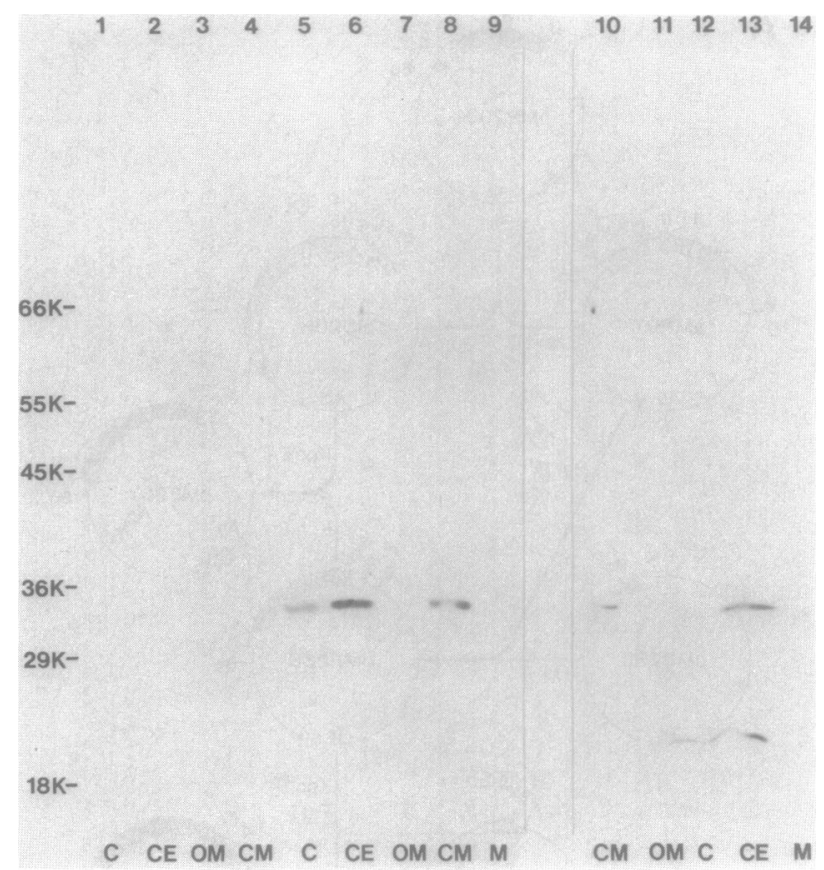

FIG. 4. Western blot (immunoblot) analysis of proteins expressed in $R$. leguminosarum by using antibodies raised against $\mathrm{p} 31$. Cell fractions of $R$. leguminosarum RBL1387(pMP238) were prepared as described in the text, and those of wild-type strain 248 were prepared in the presence of leupeptin only. NodD protein was detected in cell fractions of RBL1387(pMP238) after induction with naringenin (lanes 5 to 9 ) and in wild-type $R$. leguminosarum 248 (lanes 10 to 14). A positive reaction could not be detected in noninduced cell fractions of RBL1387(pMP238) (lanes 1 to 4) or in cell fractions of induced or uninduced RBL1387(pMP98) (data not shown). Abbreviations: C. Soluble cell proteins (lanes 1, 5, and 12); CE. total membranes (lanes 2, 6, and 13); OM, outer membrane (lanes 3, 7, and 11); CM. cytoplasmic membrane (lanes 4, 8, and 10); $M$, medium (lanes 9 and 14). Lanes containing material belonging to the same strain were each loaded with material which was derived from the same number of cells and therefore represented the total amount of NodD protein present in a given bacterial culture. The positions of molecular weight markers ( $\mathrm{K}$ indicates $10^{3}$ ) are given in the left margin.

in the cytoplasm of a NodD protein-overproducing Rhizobium strain.

Subcellular localization of NodD protein in wild-type Rhizobium cells. After we improved the methods used for the detection of NodD protein in overproducing Rhizobium cells, we were able to detect NodD protein in a concentrated cell fraction of wild-type $R$. leguminosarum biovar viciae 248. Protein fractions from the culture medium, the combined cytoplasmic and periplasmic fractions, the total membrane fraction, as well as separated inner and outer membrane fractions were electrophoresed on SDS-polyacrylamide gel. A protein with a molecular mass of $34 \mathrm{kDa}$ could only be detected on Western blots in unseparated membranes and in the cytoplasmic membrane fraction (Fig. 4, lanes 10 and 13). No signal was detected in concentrated cell fractions derived from $R$. leguminosarum RBL1387 or RBL5561 (nodD::Tn5) (data not shown). Therefore, the $34-\mathrm{kDa}$ protein of $R$. leguminosarum biovar viciae observed in Fig. 4 was indeed the NodD protein, which appeared to be localized exclusively in the cytoplasmic membrane of wild-type cells.

In Fig. 4, lanes 12 and 13, which contained soluble cell proteins and unseparated membranes, respectively, a faint 

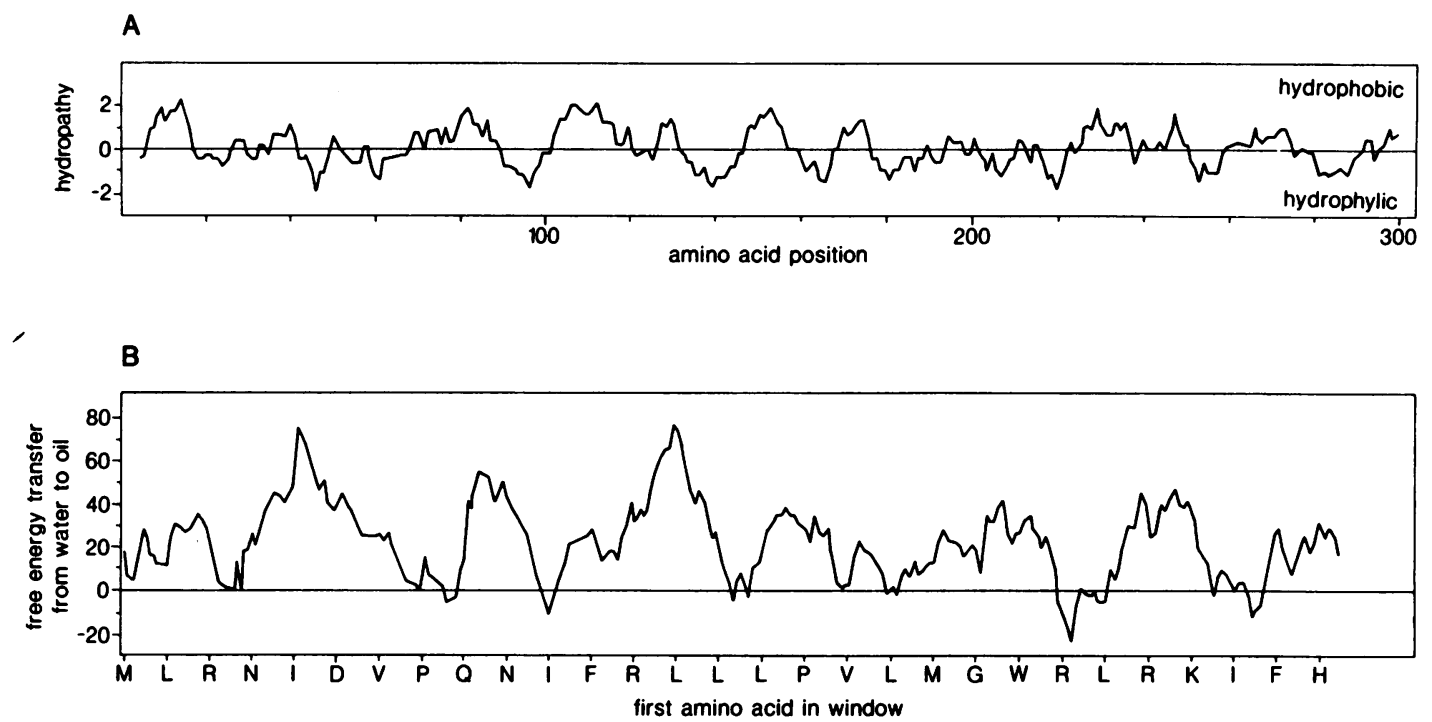

FIG. 5. Analysis of the NodD protein predicted from the nucleotide sequence of nodD of pRL1JI (34) with different computer predictions. (A) Hydrophobicity plot determined by the method of Kyte and Doolittle (17). (B) Profile giving the free energy transfer of water to oil with the algorithm of Engelman et al. (7) performed with a 16-amino-acid window width. A value of free energy equal to or less than $-20 \mathrm{kcal} / \mathrm{mol}$ means a potential membrane-spanning region. The horizontal scales of both drawings are identical.

band corresponding to an apparent molecular mass of approximately $23 \mathrm{kDa}$ could be seen as well. This phenomenon was also observed on Western blots of $R$. leguminosarum RBL1387(pMP238) when cells were fractionated in the absence of all protease inhibitors mentioned in the Materials and Methods. These results indicate that this polypeptide is a degradation product of the NodD protein. The presence of this polypeptide in the soluble cell protein fraction of $R$. leguminosarum biovar viciae 248 is probably an experimental artifact since no reaction was detected in this cell fraction after membranes were quantitatively removed by centrifugation for $16 \mathrm{~h}$ at $120,000 \times g$ in the absence of sucrose, indicating that the $23-\mathrm{kDa}$ protein is membrane bound.

The localization of the NodD protein in the cytoplasmic membrane was independent of the presence of naringenin during growth of the bacteria. We could not detect any 34-kDa protein on Western blots of the soluble cell protein fraction when this fraction was concentrated 15 -fold relative to the concentration used for the experiments for which the results are given in Fig. 4, which indicates that at least $94 \%$ of the NodD protein present in a wild-type cell is membrane associated. The presence of $1 \mathrm{M} \mathrm{NaCl}$ during the collection of membranes did not affect the localization of the NodD protein either, indicating that the membrane localization is not an artifact of electrostatic interactions.

The number of NodD protein molecules present in a wild-type Rhizobium cell was estimated to be between 20 and 80, as described in the Materials and Methods.

Prediction of NodD protein localization with computer programs. The amino acid sequence of the nodD gene of $R$. leguminosarum biovar viciae (34) was analyzed with computer programs for the prediction of several properties of the NodD protein relevant to protein localization. Several hydrophobic regions could be distinguished with the algorithm developed by Kyte and Doolittle (17), whereas the nodD gene product as a whole was not extremely hydrophobic (Fig. 5A). Using the prediction of transbilayer helices in membrane proteins (7), we found one dip of free energy transfer with a value of less than $-20 \mathrm{kcal} / \mathrm{mol}$ (Fig. 5B). This indicates a potential transmembrane position in the region flanked by Leu at position 224 and Asn at position 240 of the nodD sequence. However, this result was only obtained with a window of 16 amino acids instead of the usual window of 20 amino acids, a result which makes a membrane-spanning $\alpha$-helix at this position unlikely.

\section{DISCUSSION}

In fast-growing rhizobia, the nodD gene product positively regulates inducible Sym plasmid-localized nod genes in the presence of flavonoids. We investigated the localization of the NodD protein as a contribution to the understanding of this process.

Membrane association of NodD protein. In this report we have shown that the NodD protein is localized exclusively in the cytoplasmic membrane of wild-type cells of $R$. leguminosarum biovar viciae 248 (Fig. 4, lane 10), and only 20 to 80 molecules of the protein are estimated to be present per cell. A hydrophobicity plot (Fig. 5A) supported a membrane association of the NodD protein. It is unlikely that the NodD protein is a peripheral membrane protein because it could not be solubilized from the membrane fraction with $1 \mathrm{M}$ sodium chloride. In view of the data obtained by using the algorithm of Engelman et al. (7) (Fig. 5B), one or more transmembrane $\alpha$-helices seems unlikely as well. Analysis of the predicted nodDI gene product of $R$. meliloti with this algorithm, which was performed with a window of 20 amino acids, yielded one dip in free energy transfer with a value of less than $-20 \mathrm{kcal} / \mathrm{mol}$ (data not shown), suggesting that in this case a membrane-spanning $\alpha$-helix is possible. However, in the region involved (amino acids 259 to 279), four Pro residues were found, indicating several interruptions of the $\alpha$-helix. A membrane association of the NodD protein caused by acylation is not very likely either, since the consensus sequence Leu-Ala-Gly-Cys in the $\mathrm{N}$ termini of lipoproteins (for a review, see reference 42) is not present in the nodD gene product. This possibility requires further study, however. Based upon our current knowledge, we postulate that the NodD protein is an amphipathic protein that is inserted in the inner monolayer of the cytoplasmic membrane. 


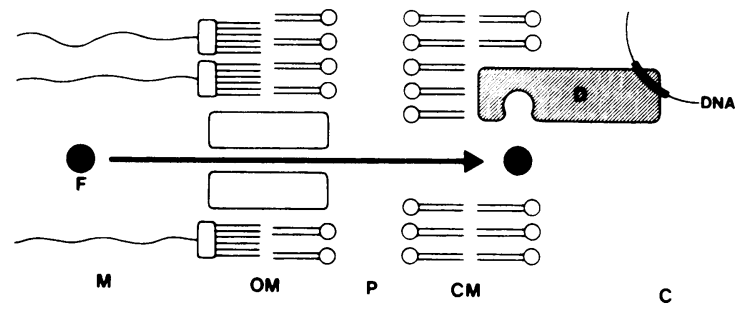

FIG. 6. Model presenting an amphipathic NodD protein localized in the cytoplasmic membrane and its interaction with nod box DNA (indicated by a black box) and flavonoids. For further explanation, see text. The presumed flavonoid binding site is not in the membrane part of NodD protein per se. Abbreviations: C, Cytoplasm; CM, cytoplasmic membrane; D. NodD protein; F, flavonoid: M, medium; OM, outer membrane; $\mathrm{P}$, periplasmic space.

Membrane localization and DNA-binding properties of NodD protein. Our finding that the NodD protein is localized in the cytoplasmic membrane was unexpected because the following data suggested that the NodD protein is localized in the cytoplasm. (i) It has been shown that the nodD gene product binds specifically at the nod box sequences present in the promoter region of inducible nod genes of $R$. meliloti (8) and $R$. leguminosarum biovar viciae (13). (ii) The NodD protein was isolated from the soluble cell protein fraction, and binding studies between the NodD protein of $R$. meliloti and nod box-containing DNA fragments have been performed with presumably soluble cell proteins derived from overproducing strains (8). This is in agreement with our observation of a relatively large amount of NodD protein in the cytosol of our overproducing strain $R$. leguminosarum RBL1387(pMP238) (Fig. 4, lane 5). (iii) The predicted NodD proteins share homology with cytoplasm-localized transcriptional regulator proteins constituting the LysR family (12) and with the $E$. coli AraC protein (34). The localization of the NodD protein is not unique for a regulatory protein, since another membrane-localized regulatory DNA-binding protein, ToxR protein, has been described (23).

NodD protein and flavonoids. It has recently become evident that nod gene expression is mediated specifically by the host $(10,15,38)$ because of the characteristic responses of nodD toward sets of flavonoids. These data strongly suggest a direct interaction between inducing compounds and the nodD gene product. Recent results from our laboratory indicate that flavonoids accumulate in the cytoplasmic membrane (27). Because the nodD gene product is the only soluble cell protein which binds specifically to nod boxes (8), it is unlikely that a second protein is involved in the information transfer between a membrane-localized NodD protein and a DNA-localized NodD protein.

Hence, we propose a model (Fig. 6) in which the NodD protein is an amphipathic protein localized in the cytoplasmic membrane with a substantial domain extending into the cytosol. It is presumed that the predicted direct interaction between the NodD protein and flavonoid inducers takes place in or close to the cytoplasmic membrane. A cytoplasmic domain of the NodD protein is supposed to be constitutively bound to nod box DNA. Activation of the NodD protein by inducers presumably causes a conformational change which initiates transcription of genes downstream of nod box-containing promoters. Our observation that the NodD protein is localized in the cytoplasmic membrane of $R$. leguminosarum biovar viciae 248 in the presence as well as in the absence of inducers supports the notion that there exists a class of DNA-binding proteins which regulates transcription in a protein-membrane-DNA complex.

\section{ACKNOWLEDGMENTS}

This work was supported in part by The Netherlands Foundation of Chemical Research and with financial aid from The Netherlands Organization for Scientific Research.

We thank Ruud de Maagd for critically reading the manuscript.

\section{LITERATURE CITED}

1. Appelbaum, E. R., D. V. Thompson, K. Idler, and N. Chartrain. 1988. Rhizobium japonicum USDA 191 has two nodD genes that differ in primary structure and function. J. Bacteriol. 170:12-20.

2. Beringer, J. E. 1974. R-factor transfer in Rhizobium leguminosarum. J. Gen. Microbiol. 84:188-198.

3. De Maagd, R. A., and B. Lugtenberg. 1986. Fractionation of Rhizobium leguminosarum cells into outer membrane, cytoplasmic membrane, periplasmic, and cytoplasmic components. J. Bacteriol. 167:1083-1085.

4. Ditta, G., S. Stanfield, D. Corbin, and D. R. Helinski. 1980. Broad host range DNA cloning system for gram-negative bacteria: construction of a gene bank of Rhizobium meliloti. Proc. Natl. Acad. Sci. USA 77:7347-7351.

5. Djordjevic, M. A., J. W. Redmond, M. Batley, and B. G. Rolfe. 1987. Clovers secrete specific phenolic compounds which either stimulate or repress nod gene expression in Rhizobium trifolii. EMBO J. 6:1173-1179.

6. Egelhoff, T. T., R. F. Fisher, T. W. Jacobs, J. T. Mulligan, and S. R. Long. 1985. Nucleotide sequence of Rhizobium meliloti 1021 nodulation genes: nodD is read divergently from $\operatorname{nod} A B C$. DNA 4:241-248.

7. Engelman, D. M., T. A. Steitz, and A. Goldman. 1986. Identifying nonpolar transbilayer helices in amino acid sequences of membrane proteins. Annu. Rev. Biophys. Chem. 15:321-353.

8. Fisher, R. F., T. T. Egelhoff, J. T. Mulligan, and S. R. Long. 1988. Specific binding of proteins from Rhizobium meliloti cell-free extracts containing NodD to DNA sequences upstream of inducible nodulation genes. Genes Dev. 2:282-293.

9. Fisher, R. F., J. A. Swanson, J. T. Mulligan, and S. R. Long. 1987. Extended region of nodulation genes in Rhizobium meliloti 1021. II. Nucleotide sequence. transcription start sites and protein products. Genetics 117:191-201.

10. Györgypal, Z., N. Iyer, and A. Kondorosi. 1988. Three regulatory nodD alleles of diverged flavonoid-specificity are involved in host-dependent nodulation by Rhizobium meliloti. Mol. Gen. Genet. 212:85-92.

11. Hager, D. A., and R. R. Burgess. 1980. Elution of proteins from sodium dodecyl sulfate-polyacrylamide gels, removal of sodium dodecyl sulfate, and renaturation of enzymatic activity: results with sigma subunit of Escherichia coli coli RNA polymerase. wheat germ DNA topoisomerase, and other enzymes. Anal. Biochem. 109:76-86.

12. Henikoff, S., G. W. Haughn, J. M. Calvo, and J. C. Wallace. 1988. A large family of bacterial activator proteins. J. Bacteriol. 170:6602-6606.

13. Hong, G. F., J. E. Burn, and A. W. B. Johnston. 1987. Evidence that DNA involved in the expression of nodulation (nod) genes in Rhizobium binds to the product of the regulatory gene nodD. Nucleic Acids Res. 15:9677-9690.

14. Honma, M. A., and F. M. Ausubel. 1987. Rhizobium meliloti has three functional copies of the nodD symbiotic regulatory gene. Proc. Natl. Acad. Sci. USA 84:8558-8562.

15. Horvath, B., C. W. B. Bachem, J. Schell, and A. Kondorosi. 1987. Host-specific regulation of nodulation genes in Rhizobium is mediated by a plant-signal, interacting with the nodD gene product. EMBO J. 6:841-848.

16. Josey, D. P., J. L. Beynon, A. W. B. Johnston, and J. B. Beringer. 1979. Strain identification in Rhizobium using intrinsic antibiotic resistance. J. Appl. Microbiol. 46:343-350.

17. Kyte, J., and R. F. Doolittle. 1982. A simple method for displaying the hydropathic character of a protein. J. Mol. Biol. 157:105-132.

18. Lugtenberg, B., J. Meyers, R. Peters, P. Van der Hoek, and L. Van Alphen. 1975. Electrophoretic resolution of the major outer membrane protein of Escherichia coli $\mathrm{K} 12$ into four bands. FEBS Lett. 58:254-258. 
19. Maniatis, T., E. F. Fritsch, and J. Sambrook. 1982. Molecular cloning: a laboratory manual, 1st ed. Cold Spring Harbor Laboratory, Cold Spring Harbor, N.Y.

20. Markwell, M. A. K., S. M. Haas, L. L. Bieber, and N. E. Tolbert. 1978. A modification of the Lowry procedure to simplify protein determination in membrane and lipoprotein samples. Anal. Biochem. 87:206-210.

21. Marsh, J. L., M. Erfle, and E. J. Wykes. 1984. The pIC plasmid and phage vectors with versatile cloning sites for recombinant selection by insertional inactivation. Gene 32:481-485.

22. Miller, J. H. 1972. Experiments in molecular genetics, 1st ed. Cold Spring Harbor Laboratory, Cold Spring Harbor, N.Y.

23. Miller, V. L., R. K. Taylor, and J. J. Mekalanos. 1987. Cholera toxin transcriptional activator ToxR is a transmembrane DNA binding protein. Cell 48:271-279.

24. Mulligan, J. T., and S. R. Long. 1985. Induction of Rhizobium meliloti nodC expression by plant exudate requires nodD. Proc. Natl. Acad. Sci. USA 82:6609-6613.

25. Osborn, M. J., J. E. Gander, E. Parisi, and J. Carson. 1972. Mechanism of assembly of the outer membrane of Salmonella typhimurium. J. Biol. Chem. 247:3962-3972.

26. Priem, W. J. E., and C. A. Wijffelman. 1984. Selection of strains cured of the Rhizobium leguminosarum Sym plasmid pRL1JI by using small bacteriocin. FEMS Microbiol. Lett. 25:247-251.

27. Recourt, K., A. A. N. Van Brussel, A. J. M. Driessen, and B. J. J. Lugtenberg. 1989. Accumulation of a nod gene inducer, the flavonoid naringenin, in the cytoplasmic membrane of Rhizobium leguminosarum biovar viciae is caused by the $\mathrm{pH}$ dependent hydrophobicity of naringenin. J. Bacteriol. 171:4370 4377.

28. Rossen, L., C. A. Shearman, A. W. B. Johnston, and J. A Downie. 1985. The nodD gene of Rhizobium leguminosarum is autoregulatory and in the presence of plant exudate induces the nodA, $B, C$ genes. EMBO J. 4:3369-3373.

29. Rostas, K., E. Kondorosi, B. Horvath, A. Simoncsits, and A. Kondorosi. 1986. Conservation of extended promoter regions of nodulation genes in Rhizobium. Proc. Natl. Acad. Sci. USA 83: 1757-1761.

30. Sanger, F., S. Nicklen, and A. R. Coulson. 1977. DNA sequencing with chain-terminating inhibitors. Proc. Natl. Acad. Sci. USA 74:5463-5467.

31. Schell, M. A., and E. F. Poser. 1989. Demonstration, characterization, and mutational analysis of NahR protein binding to nah and sal promoters. J. Bacteriol. 171:837-846.

32. Schofield, P. R., and J. M. Watson. 1986. DNA sequence of the Rhizobium trifolii nodulation genes reveals a reiterated and potentially regulatory sequence preceding the nodABC and nodFE genes. Nucleic Acids Res. 14:2891-2905.
33. Scott, K. F. 1986. Conserved nodulation genes from the nonlegume symbiont Bradyrhizobium sp. (Parasponia). Nucleic Acids Res. 14:2905-2919.

34. Shearman, C. A., L. Rossen, A. W. B. Johnston, and J. A. Downie. 1986. The Rhizobium leguminosarum nodulation gene $n o d F$ encodes a polypeptide similar to acyl-carrier protein and is regulated by nodD plus a factor in pea-root exudate. EMBO J. 5:647-652.

35. Spaink, H. P., R. J. H. Okker, C. A. Wijffelman, E. Pees, and B. J. J. Lugtenberg. 1987. Promoters in the nodulation region of the Rhizobium leguminosarum symplasmid pRL1JI. Plant Mol. Biol. 9:27-39.

36. Spaink, H. P., R. J. H. Okker, C. A. Wijffelman, T. Tak, L. Goosen-de Roo, E. Pees, A. A. N. Van Brussel, and B. J. J. Lugtenberg. 1989. Symbiotic properties of rhizobia containing a flavonoid-independent hybrid nodD product. J. Bacteriol. 171: 4045-4053.

37. Spaink, H. P., C. A. Wijffelman, R. J. H. Okker, and B. J. J. Lugtenberg. 1989. Localization of functional regions of the Rhizobium nodD product using hybrid nodD genes. Plant Mol Biol. 12:59-73.

38. Spaink, H. P., C. A. Wijffelman, E. Pees, R. J. H. Okker, and B. J. J. Lugtenberg. 1987. Rhizobium nodulation gene nodD as a determinant of host specificity. Nature (London) 328:337-339.

39. Towbin, H., T. Staehelin, and J. Gordon. 1979. Electrophoretic transfer of proteins from polyacrylamide gels to nitrocellulose sheets: procedure and some applications. Proc. Natl. Acad. Sci. USA 76:4350-4354.

40. Van Brussel, A. A. N., K. Planque, and A. Quispel. 1977. The wall of Rhizobium leguminosarum in bacteroid and free-living forms. J. Gen. Microbiol. 101:51-56.

41. Van der Meide, P. H., M. Dubbeld, and H. Schellekens. 1985. Monoclonal antibodies to human immune interferon and their use in a sensitive solid-phase ELISA. J. Immunol. Methods 79: 293-305.

42. Wu, H. C., J.-S. Lai, S. Hayashi, and C.-Z. Giam. 1982 Biogenesis of membrane lipoproteins in Escherichia coli. Biophys. J. 37:307-315.

43. Yanisch-Perron, C., J. Vieira, and J. Messing. 1985. Improved M13 phage cloning vectors and host strains: nucleotide sequences of the M13 mp18 and pUC19 vectors. Gene 33:103-119.

44. You, I.-S., D. Ghosal, and C. Gunsalus. 1988. Nucleotide sequence of plasmid Nah7 gene nahR and DNA binding of the nahR product. J. Bacteriol. 170:5409-5415.

45. Zaat, S. A. J., C. A. Wijffelman, H. P. Spaink, A. A. N. Van Brussel, R. J. H. Okker, and B. J. J. Lugtenberg. 1987. Induction of the nodA promoter of Rhizobium leguminosarum sym plasmid pRL1JI by plant flavanones and flavones. J. Bacteriol. 169:198-204. 